\title{
Early clinical experience with the Hancock porcine xenograft valve prosthesis
}

\author{
C. T. M. SANG ${ }^{1}$, J. WALLWORK ${ }^{2}$, H. C. MILLER, A. H. KITCHIN, \\ K. G. DAVIDSON ${ }^{2}$, AND P. K. CAVES
}

From the Departments of Cardiothoracic Surgery and Cardiology, Royal Infirmary, Edinburgh; and Department of Cardiology, Western General Hospital, Edinburgh

SUMMARY In a 2-year period, 75 Hancock porcine xenograft valves were inserted in 66 patients, 33 male and 33 female. Their average age was 55 years (range 14 to 69 years). The indication for operation was rheumatic heart disease (30 patients), prosthetic valve dysfunction ( 8 patients), papillary muscle dysfunction ( 8 patients), degenerative valve disease (13 patients), subacute bacterial endocarditis ( 3 patients), luetic valve disease ( 2 patients), congenital heart disease ( 1 patient), and traumatic valve damage ( 1 patient).

Forty-five valves were placed in the mitral, 28 in the aortic, and 2 in the tricuspid position; 9 patients required double valve replacement. Additional operative procedures included coronary artery vein bypass grafts (12 patients), tricuspid annuloplasty ( 6 patients), left ventricular aneurysmectomy (4 patients), open mitral valvotomy ( 3 patients), replacement of ascending aorta ( 1 patient), and closure of ventricular septal defect ( 1 patient). There were 2 hospital deaths $(3 \%)$. Oral anticoagulation was continued for approximately 6 weeks postoperatively, when it was discontinued in all but 8 patients.

In the follow-up period-mean 16 months (range 8 to 31 months)-there were 4 late deaths, 2 of which were sudden. There was no documented episode of thromboembolism or valve degeneration. All except 2 patients were clinically improved from NYHA class III or IV preoperatively to class I or II postoperatively.

Initial results with Hancock porcine xenograft valves are most satisfactory and compare more than favourably with other commercially available valve substitutes.

The ideal heart valve substitute should be readily available, easily inserted, free from thromboembolic and infectious complications, haemodynamically satisfactory, and durable in the long term.

Dissatisfaction with the thrombogenicity, haemodynamic performance, and long-term durability of many mechanical prostheses (Stanford et al., 1972; Vidne et al., 1973) has led to the increasing use of many different types of tissue valves (Ionescu et al., 1974; Wallace, 1975).

Of the tissue valves commercially available, the porcine aortic xenograft prepared by the 'stabilised glutaraldehyde process' and mounted on a flexible polypropylene Dacron-covered stent (Hancock

'Present address: Department of Cardiothoracic Surgery, Guy's Hospital, London.

2Present address: University Department of Cardiac Surgery, Royal Infirmary, Glasgow.

Received for publication 1 June 1978
Laboratories) has gained wide clinical acceptance. This valve was first used in Edinburgh in November 1973 and we report our initial clinical experience with it.

\section{Subjects and methods}

In a two-year period from November 1973, 75 Hancock valves were inserted into 66 consecutive patients at Edinburgh Royal Infirmary. There were 33 male and 33 female patients. The patients' ages ranged from 14 to 69 years (mean 55 years) (Fig. 1). Preoperatively, all patients were in class III or IV (New York Heart Association classification) (Fig. 2).

Forty-five valves were placed in the mitral position, 28 in the aortic, and 2 in the tricuspid position. Valve sizes ranged from between nos. 29 and 35 in the mitral position, nos. 21-29 in the aortic position, and no. 33 in the tricuspid position.

Of 57 single valve replacements, 36 patients had 


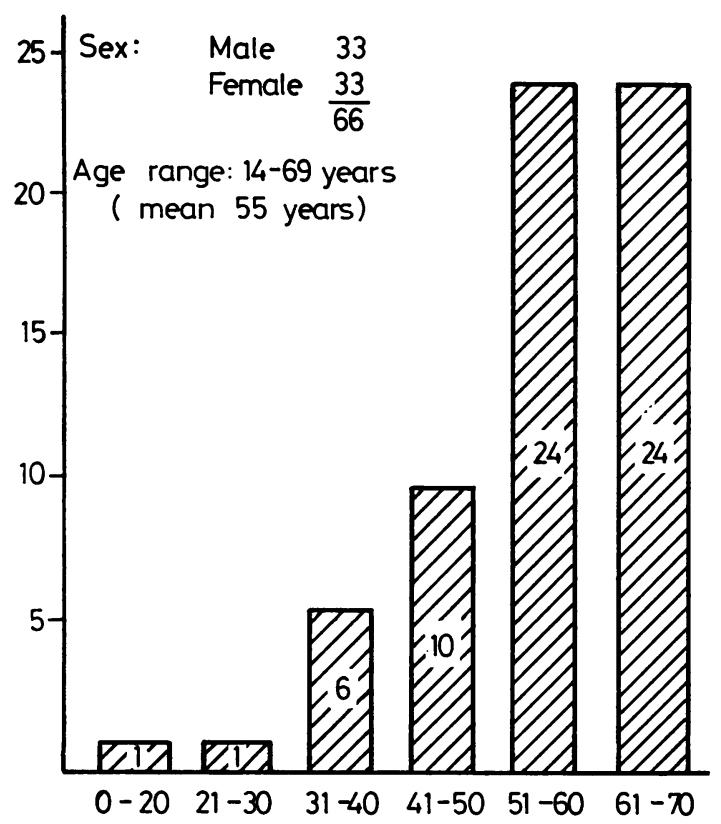

Fig. 1 Age and sex of patients.

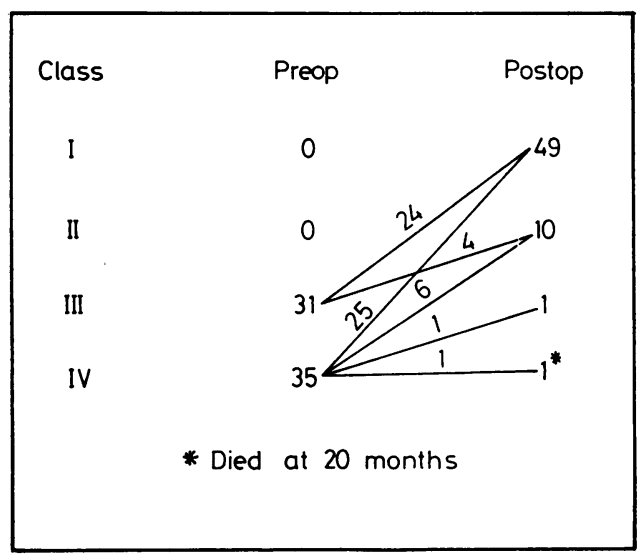

Fig. 2 Symptomatic improvement (NYHA classification). mitral valve replacement and 21 aortic valve replacement.

Seven patients had double valve replacement (aortic and mitral) and 2 patients underwent mitral and tricuspid valve replacement (Table 1).

Additional procedures in 27 patients included 1 to 4 saphenous vein aortocoronary bypass grafts (12 patients), tricuspid annuloplasty (6 patients), resection of left ventricular aneurysm (4 patients), open mitral valvotomy ( 3 patients), replacement of the ascending aorta ( 1 patient), and closure of ventricular septal defect ( 1 patient).

In 53 patients in whom coronary artery disease was either excluded by selective coronary angiography or was not suspected, there was 1 death (mortality $1.9 \%$ ) after a single aortic valve replacement (Table 2).

In 13 patients, the presence of ischaemic heart disease was proved preoperatively by selective coronary angiography and left ventricular angiography. In 12 of these patients, valve replacement was combined with coronary artery vein bypass grafting without mortality. One patient, submitted to aortic and mitral valve replacement and left ventricular aneurysmectomy without coronary artery grafting, died intraoperatively, giving a hospital mortality for this group of $\mathbf{7 . 7}$ per cent (Table 3).

The aetiology of the valvular disease in the different patient groups is shown in Tables 4, 5, 7, and 8.

Table 2 Valve replacement in patients without ischaemic heart disease

\begin{tabular}{lc}
\hline Mitral valve replacement & 28 \\
Aortic valve replacement & $18^{\star}$ \\
Mitral + aortic valve replacement & 5 \\
Mitral + tricuspid valve replacement & $\frac{2}{23}$ \\
Total & $1 \quad(1 \cdot 9 \%)$ \\
^Hospital death & \\
Additional procedures: & 6 \\
Tricuspid annuloplasty & 2 \\
Mitral valvotomy & 1 \\
Replacement ascending aorta & $\frac{9}{}$ \\
Total &
\end{tabular}

Table 1 Valve replacement and prosthetic size

\begin{tabular}{|c|c|c|c|c|c|}
\hline & $\begin{array}{l}\text { No. of } \\
\text { patients }\end{array}$ & Valve(s) replaced & Valve replaced & $\begin{array}{l}\text { No. of } \\
\text { patients }\end{array}$ & Prosthetic size (range) \\
\hline $\begin{array}{l}\text { Single valve } \\
\text { Double valve }\end{array}$ & $\begin{array}{r}57 \\
9\end{array}$ & $\begin{array}{l}\text { MV 36; AV 21 } \\
M V+A V 7 ; M V+T V 2\end{array}$ & $\begin{array}{l}\text { Mitral } \\
\text { Aortic } \\
\text { Tricuspid }\end{array}$ & $\begin{array}{r}45 \\
28 \\
2\end{array}$ & $\begin{array}{l}\text { Nos. } 29-35 \\
\text { Nos. } 21-29 \\
\text { No. } 33\end{array}$ \\
\hline Total & 66 & & Total & 75 & \\
\hline
\end{tabular}


Table 3 Valve replacement in patients with ischaemic heart disease

\begin{tabular}{lc}
\hline $\begin{array}{l}\text { Mitral valve replacement + coronary artery bypass } \\
\text { graft }\end{array}$ & 6 \\
$\begin{array}{l}\text { Aortic valve replacement + coronary artery bypass } \\
\text { graft }\end{array}$ & 2 \\
$\begin{array}{l}\text { Mitral valve replacement + coronary artery bypass } \\
\text { graft + LV aneurysmectomy }\end{array}$ & 1 \\
$\begin{array}{l}\text { Aortic valve replacement + coronary artery bypass } \\
\text { graft + LV aneurysmectomy }\end{array}$ & 1 \\
$\begin{array}{l}\text { Mitral valve + aortic valve replacement + coronary } \\
\text { artery bypass graft }\end{array}$ & 1 \\
$\begin{array}{l}\text { Mitral valve + aortic valve replacement + LV } \\
\text { aneurysmectomy }\end{array}$ & $1 \star$ \\
$\begin{array}{l}\text { Mitral valve replacement + coronary artery bypass } \\
\text { graft + LV aneurysmectomy + closure of VSD }\end{array}$ & 1 \\
$\begin{array}{l}\text { Total } \\
\text { *Hospital death }\end{array}$ & 13 \\
\hline
\end{tabular}

Table 4 Aetiology of valve disease

\begin{tabular}{lr}
\hline Rheumatic heart disease & 30 \\
Prosthetic valve dysfunction & 8 \\
Papillary muscle dysfunction & 8 \\
Degenerative valve disease & 13 \\
Subacute bacterial endocarditis & 3 \\
Luetic valve disease & 2 \\
Congenital heart disease & 1 \\
Traumatic valve damage & 1 \\
Total & 66 \\
\hline
\end{tabular}

Table 5 Indications for mitral valve replacement

\begin{tabular}{lr}
\hline Rheumatic heart disease & 22 \\
Prosthetic valve dysfunction & 4 \\
Papillary muscle fibrosis & 1 \\
Papillary muscle rupture & 4 \\
Ruptured chordae tendineae & 4 \\
Q fever endocarditis & 1 \\
Total & -36
\end{tabular}

Hospital mortality 0

Table 6 Previous operations performed in 35 patients with rheumatic mitral valve disease

\begin{tabular}{|c|c|}
\hline Operation & $\begin{array}{l}\text { No. of } \\
\text { patients }\end{array}$ \\
\hline $\begin{aligned} \text { Closed mitral valvotomy } & \times 1 \\
& \times 2 \\
& \times 3\end{aligned}$ & $\begin{array}{l}9 \\
2 \\
1\end{array}$ \\
\hline $\begin{array}{l}\text { Closed mitral valvotomy }+ \text { mitral valve replacement } \\
\text { Closed mitral valvotomy } \times 3+\text { mitral valve } \\
\text { replacement }\end{array}$ & 2 \\
\hline $\begin{array}{l}\text { Closed mitral valvotomy }+ \text { aortic valve replacement } \\
\text { Closed mitral and aortic valvotomy }+ \text { mitral and aortic }\end{array}$ & 1 \\
\hline $\begin{array}{l}\text { valve replacement } \\
\text { Mitral valve replacement } \\
\text { Replacement of mitral valve prosthesis }\end{array}$ & $\begin{array}{l}1 \\
2 \\
1\end{array}$ \\
\hline Total (32 operations) & $\overline{20}$ \\
\hline
\end{tabular}

Table 7 Indications for aortic valve replacement

\begin{tabular}{lc}
\hline Rheumatic heart disease & $5^{\star}$ \\
Calcific aortic stenosis & 11 \\
Subacute bacterial endocarditis & 2 \\
Luetic valve disease & 2 \\
Traumatic valve rupture & 1 \\
Total & 21 \\
$\star$ Hospital mortality & $1 \quad(4 \cdot 8 \%)$ \\
\hline
\end{tabular}

Table 8 Indications for double valve replacement

\begin{tabular}{ll}
\hline Rheumatic heart disease & 3 \\
Prosthetic valve dysfunction + rheumatic heart & 3 \\
disease & 1 \\
$\begin{array}{l}\text { Double prosthetic valve dysfunction } \\
\text { Marfan's syndrome }\end{array}$ & 1 \\
$\begin{array}{l}\text { Calcific aortic stenosis }+ \text { ischaemic mitral } \\
\text { regurgitation }\end{array}$ & $1 \star$ \\
Total & 9 \\
$\star$ *Hospital mortality & $1 \quad(11 \cdot 1 \%)$ \\
\hline
\end{tabular}

Of the 35 patients whose first presentation for cardiac surgery had been with rheumatic mitral valve disease, 20 had already been submitted to a variety of surgical procedures (Table 6).

\section{SURGICAL TECHNIQUE}

Standard bicaval-aortic route cardiopulmonary bypass, using a disposable bubble oxygenator and roller pump, was employed. Flow rates varied between 2 and 3.5 litres/min with a mean arterial pressure between 40 and $70 \mathrm{mmHg}$. Mild hypothermia down to $31^{\circ} \mathrm{C}$ was reached in most patients.

All operations were performed through a vertical median sternotomy incision. The aorta was crossclamped throughout the intracardiac procedures, the myocardium being protected by continuous irrigation with cold saline solution at $4^{\circ} \mathrm{C}$. Horizontal mattress sutures were used to secure all valves and the struts of the mitral and tricuspid prostheses were orientated so as to produce minimal obstruction to ventricular outflow.

Oral anticoagulation with warfarin was started on the first postoperative day and was discontinued after 6 weeks, except in those patients with a previous history of an embolism, left atrial thrombus at operation, or a giant left atrium.

\section{Results}

There were 2 hospital deaths (mortality rate 3\%). One patient with calcific aortic stenosis and mitral regurgitation with coronary artery disease did not have a preoperative left ventricular cineangiogram as the aortic valve could not be crossed. At operation. 
Table 9 Late mortality

\begin{tabular}{lllll}
\hline Patient & Operation & $\begin{array}{c}\text { Survival } \\
(m t h)\end{array}$ & Cause of death & $\begin{array}{c}\text { Valve } \\
\text { histologv }\end{array}$ \\
\hline 1 & $\begin{array}{c}\text { Mitral valve replacement }+ \text { coronary artery vein } \\
\text { bypass graft } \times 4\end{array}$ & 2 & $\begin{array}{c}\text { Congestive cardiac failure; left atrial clot at } \\
\text { necropsy }\end{array}$ & Normal \\
2 & $\begin{array}{c}\text { Replacement of aortic valve prosthesis }+ \text { mitral } \\
\text { valve replacement }+ \text { tricuspid annuloplasty }\end{array}$ & 3 & Cause unknown & Normal \\
3 & Mitral valve replacement & 4 & $\begin{array}{c}\text { Congestive cardiac failure with gross cardiomegaly; Normal } \\
\text { left atrial clot at necropsy }\end{array}$ \\
4 & Replacement of mitral valve prosthesis & 20 & $\begin{array}{c}\text { Congestive cardiac failure with gross cardiomegaly; Normal } \\
\text { extensive myocardial fibrosis and left ventricle } \\
\text { thrombus at necropsy }\end{array}$ \\
\hline
\end{tabular}

Table 10 Long-term follow-up

\begin{tabular}{lc}
\hline No. of patients & 64 \\
Period of follow-up & 8 to 31 months (mean 16 months) \\
Total follow-up period & 1026 months \\
Long-term anticoagulation & 8 patients \\
Valve failure & 0 \\
Valve infection & 0 \\
Episodes of thromboembolism & 1 \\
\hline
\end{tabular}

he was found to have a large left ventricular aneurysm with mitral valve papillary muscle dysfunction. After left ventricular aneurysmectomy, aortic and mitral valve replacement, the operation was concluded without incident. He suddenly developed ventricular fibrillation after wound closure and could not be resuscitated. The second hospital death occurred in a 69-year-old man submitted to aortic valve replacement, and was the consequence of laceration of the subclavian artery during insertion of a central venous pressure monitoring line. He was reopened on several occasions for bleeding before the bleeding point was identified, had massive blood transfusion, and died after 24 days from multiple system failure.

During the mean follow-up period of 16 months (range 8 to 31), there were 4 late deaths at 2, 3, 4, and 20 months. All occurred in patients with a long preoperative history of heart disease and congestive cardiac failure.

Necropsy was carried out in all patients. In 2, thrombus was found in the left atrium and in a third, with myocardial fibrosis and gross cardiomegaly, thrombus was found in the left ventricle. No thrombus was found on the prosthetic valves which were macroscopically and microscopically normal in every case.

FOLLOW-UP

Sixty-four patients were discharged and followed up for a total of 1026 months or 16 months/patient (range 8 to 30 months). Long-term anticoagulation was continued after 6 weeks in only 8 patients. There was no incidence of valve failure or infection or of paraprosthetic leak. One patient had transient blindness of one eye during the first 6 weeks while still on anticoagulation, from which he fully recovered. No other known or suspected embolic episodes were experienced.

\section{SYMPTOMATIC IMPROVEMENT}

Of 31 patients in class III (NYHA classification) preoperatively, 3 died, 24 improved to class I, and 4 to class II. Thirty-five patients were class IV preoperatively; 25 improved to class I, 6 to class II, and 1 to class III. One patient remained in class IV until death at 20 months and 2 other patients died.

Actuarial survival curves show an overall survival rate of just under 80 per cent at $2 \frac{1}{2}$ years. Over this period, survival after mitral valve replacement was 80.2 per cent and survival for valve replacement in association with ischaemic heart disease was 84.6 per cent at 36 months. For double valve replacement survival was 85.7 per cent at 2 years, and for single aortic valve replacement survival was 94.5 per cent at 18 months.

\section{Discussion}

The results of this study confirm the findings of others (Ionescu et al., 1972; Brown et al., 1974; Carpentier et al., 1974; Horowitz et al., 1974; Stinson et al., 1974; Zuhdi, 1974; Zuhdi et al., 1974; Cohn et al., 1975; Pipkin et al., 1976) that the porcine aortic xenograft bioprosthesis (Hancock Laboratories) functions very well as a heart valve substitute in the mitral, aortic, and tricuspid position in man.

A particular feature in these patients was the rapid and smooth immediate postoperative recovery that the majority enjoyed and which was attributed 
to the very favourable haemodynamic characteristics of these valves. Improvement in at least two functional classes was seen in 98 per cent of the surviving patients. Failure to obtain symptomatic improvement was related in one patient to myocardial disease after 3 previous mitral valve procedures, and to non-cardiac causes in another patient with osteoarthritis.

Serious valve-related problems were extremely few. In particular, there was no incidence of valve failure or infection over the first $2 \frac{1}{2}$ years postoperatively and there was only one probable episode of systemic embolisation. This occurred during the first 6 postoperative weeks while the patient was still on oral anticoagulation, a time when the valve sewing ring is not yet endothelialised and when the risk of systemic embolisation is known to be highest with all prostheses.

After this first 6-week period, anticoagulation with its attendant morbidity and mortality (Stanford et al., 1972; Cleland and Molloy, 1973; Vidne et al., 1973) was avoided in the large majority of patients $(87 \%)$. It is possible that thrombus formation in the left atrium may have had a part to play in the sudden death of 2 patients comparatively soon after their oral anticoagulation had been discontinued. Because of our experience with these patients, we are now inclined to keep most patients on long-term oral anticoagulation after mitral valve replacement with a Hancock prosthesis if they have more than moderate left atrial enlargement and are in atrial fibrillation, and particularly if there is clot in the left atrium at the time of operation.

The durability of these valves, with not one single valve failure occurring throughout the follow-up period, has been most encouraging and is in striking contrast to the experience with many other earlier forms of tissue valve prosthesis, where there has been a steady attrition rate from the early postoperative period (Wallace, 1975). This improved durability has been largely attributed to 2 factors. The use of a flexible stent has been shown to reduce stress at the cusp edges on closure up to 90 per cent (Reis et al., 1971); secondly, the glutaraldehyde process used to 'tan' the valve is known to produce much more stable cross-linkage between the collagen fibres of the leaflets than has been achieved with previous preservation methods (Carpentier et al., 1969).

In our opinion, the Hancock porcine xenograft prosthesis fulfils many of the characteristics of an ideal human valve substitute and compared more than favourably with other commercially available valve substitutes.

\section{References}

Brown, J. W., Myerowitz, P. D., Cann, M. S., Colvin, S. B. McIntosh, C. L., and Morrow, A. G. (1974). Clinical and haemodynamic comparisons of Kay-Shiley, StarrEdwards No. 6520 and Hancock porcine xenograft mitral valves. Surgery, 76, 983-991.

Carpentier, A., Deloche, A., Relland, J., Fabiani, I. N., Forman, J., Camilleri, J. P., Soyer, R., and Dubost, A. (1974). Six year follow up of gluteraldehyde preserved heterografts. Fournal of Thoracic and Cardiovascular Surgery, 68, 771-782.

Carpentier, A., Lemaigre, G., Robert, L., Carpentier, S., and Dubost, C. (1969). Biological factors affecting longterm results of valvular heterografts. Fournal of Thoracic and Cardiovascular Surgery, 58, 467-483.

Cleland, J., and Molloy, P. J. (1973). Thromboembolic complications of cloth covered Starr-Edwards prosthesis No. 2300 aortic and No. 6300 mitral. Thorax, 28, 41-47.

Cohn, L. H., Lambert, J. J., Castaneda, A. R., and Collins, J. J., !r. (1975). Cardiac valve replacement with the stabilized gluteraldehyde porcine aortic valve: indicaticns, operative results and follow up. Chest, 68, 162-165.

Horowitz, M. S., Goodman, D. J., Fogarty, T. J., and Harrison, D. C. (1974). Mitral valve replacement with the gluteraldehyde preserved porcine heterograft. fournal of Thoracic and Cardiovascular Surgery, 67, 885-895.

Ionescu, M. I., Pakrashi, B. C., Mary, D. A. S., Bartek, I. T. and Wooler, G. H. (1974). Long term evaluation of tissue valves. Fournal of Thoracic and Cardiovascular Surgery, 68, 361-378.

Ionescu, M. I., Smith, D. R., Sutherland, T. W., and Wooler, G. H. (1972). Heart valve replacement with aortic heterografts. Annals of Thoracic Surgery, 13, 1-14.

Pipkin, R. D., Buch, W. S., and Fogarty, M. D. (1976). Evaluation of aortic valve replacement with a porcine xenograft without long term anticoagulation. fournal of Thoracic and Cardiovascular Surgery, 71, 179-186.

Reis, A. L., Hancock, W. D., Yarbrough, J. W., Glancy, D. L., and Morrow, A. G. (1971). The flexible stent. A new concept in the fabrication of tissue heart valve prostheses. Fournal of Thoracic and Cardiovascular Surgery, 62, 683-689.

Stanford, W., Lundberg, E. F., and Armstrong, W. G. (1972). Implantation of heart valve prostheses without anticoagulants. Fournal of Thoracic and Cardiovascular Surgery, 63, 648-651.

Stinson, E. B., Griepp, R. B., and Shumway, N. E. (1974). Clinical experience with a porcine aortic valve xenograft for mitral valve replacement. Annals of Thoracic Surgery, 18, 391-401.

Vidne, B., Erdman, S., and Levy, M. I. (1973). Thromboembolism following heart valve replacement by prosthesis : survey among 365 consecutive patients. Chest, 63, 713-717.

Wallace, R. B. (1975). Tissue valves. American fournal of Cardiology, 35, 866-871.

Zuhdi, N. (1974). 'Stabilised gluteraldehyde process' xenograft heart valves-results from nine centres. Presented at the Society of Thoracic Surgeons' Annual Meeting, Los Angeles, California, January. Little Brown, Boston.

Zuhdi, N., Hawley, W., Voehi, V., Hancock, W. D., Carey, J., and Greer, A. (1974). Porcine aortic valves as replacement for human heart valves. Annals of Thoracic Surgery, 17, 479-491.

Requests for reprints to J. Wallwork, Esq., F.R.C.S., Department of Cardiac Surgery, Royal Infirmary, Glasgow G4 OSF. 